\title{
A 27-kg mucinous cystadenoma of the ovary presenting with deep vein thrombosis
}

\section{Derin venöz trombozla prezente olan 27 kg’lik overyan müsinöz kistadenom}

\author{
Esra Nur Tola1, Evrim Erdemoğlu², Yakup Yalçın², Filiz Alkaya Solmaz ${ }^{3}$, Ebru Erdemoğlu4 \\ 1 Süleyman Demirel University Faculty of Medicine, Department of Gynecology and Obstetrics, Isparta, Turkey \\ 2 Süleyman Demirel University Faculty of Medicine, Department of Gynecologic Oncology, Isparta, Turkey \\ 3 Süleyman Demirel University Faculty of Medicine, Department of Anestesiology and Reanimation, Isparta, Turkey \\ ${ }^{4}$ Şifa Hospital, Clinic of Gynecology and Obstetrics, Isparta, Turkey
}

\begin{abstract}
Giant ovarian adenomas are rarely observed today because of early diagnosis and treatment. Mucinous cystadenomas is a kind of tumor that mostly causes the ovary to enlarge. Theu can present with various and non-specific clinical manifestations such as deep vein thrombosis. The primary symptoms of giant ovarian tumors are abdominal enlargement and distension. Therefore, making the correct preoperative diagnosis is sometimes difficult. The appropriate treatment must include oncologic procedures and a multidisciplinary approach to minimalize complications and save the patient's life. Herein, we report a woman aged 53 years with a $27-\mathrm{kg}$ ovarian mucinous cystadenoma that presented as a left popliteal vein thrombosis. Keywords: Abdominal enlargement, deep vein trombosis, giant ovarian tumour, ovarian mucinous cystadenoma

$\ddot{\mathbf{O} z}$

Günümüzde erken tanı ve tedaviden dolayı büyük overyan adenomlar nadir görülmektedir. Müsinöz kistadenomlar, overi en çok büyüten tümörlerdir. Derin venöz tromboz gibi çok çeşitli ve non-spesifik klinik manifestasyonları olabilir ve major semptomu abdominal genişleme ve distansiyondur. Bu yüzden preoperatif doğru tanı koymak bazen zor olabilir. Hastanın hayatını kurtarmak ve komplikasyonları azaltmak için tedavi onkolojik prosedürleri içermeli ve multidisipliner bir yaklaşım olmalıdır. Burada, sol popliteal venöz trombozu ile gelen 27 kg overyan müsinöz kistadenomlu 53 yaşında bir hastayl sunuyoruz.
\end{abstract}

Anahtar Kelimeler: Abdominal genişleme, derin venöz trombozu, büyük overyan tümör, overyan müsinöz kistadenom

\section{Introduction}

Giant ovarian tumours are now a rare condition because of early diagnosis and treatment. Mucinous cystadenoma (MCA), a tumor that causes ovaries to enlarge, accounts for about $15 \%$ of all ovarian neoplasms(1,2). About $80 \%$ of mucinous tumors are benign and are common usually between the third and sixth decade of life(2,3). Mucinous tumors are usually unilateral and can exceed $30 \mathrm{~cm}$ in diameter(4). Although prognosis is very good, the clinical signs and symptoms of ovarian masses are generally nonspecific. Therefore, making the correct preoperative diagnosis is sometimes difficult, and early management may be necessary to save the patient's life. The purpose of this case was to report a $27-\mathrm{kg}$ ovarian MCA that presented as deep vein thrombosis (DVT).

\section{Case Report}

The patient was a woman aged 53 years with an abdominal mass that caused left popliteal and femoral vein thrombosis. She claimed stepwise enlargement of the abdomen and initially thought she had put on weight. However, when swelling progressed in her left leg, she was admitted to an internal medicine clinic. Her condition was diagnosed as DVT and she was referred to us upon finding an abdominal mass in her abdominal ultrasound (USG) examination. Abdominal enlargement and distension were observed, and abdominal USG revealed a $40 \times 50 \mathrm{~cm}$ abdominopelvic mass, probably 
originating from her left ovary, with multiple septations and solid areas. Tumor markers (CA 19-9, CA 125) were within the normal range. A malignant ovarian tumor was initially suspected because of the size, and a positron-emission tomographycomputerized tomography (PET-CT) was performed. The PETCT revealed an enormous heterogenic mass with low metabolic activity in the left ovary, a $5 \times 5 \mathrm{~cm}$ mass in the right ovary, and bilateral urinary stasis. A laparotomy with midline incision revealed a smooth-surfaced mass that filled the entire abdomen originating from the left ovary and confirmed the $5 \times 5 \mathrm{~cm}$ mass in the right ovary (Figure 1). A detailed pelvic examination was performed because of the risk of borderline potential, and it did not indicate metastases. There was minimal free fluid in the pouch of Douglas. The patient had hypotension and bradycardia, and we quickly decided to operate in the lateral position to prevent hemodynamic derangements. The ovarian masses were sent for frozen sectioning. A hysterectomy and bilateral salpingo-oophorectomy was performed because of the giant size of the cystic mass, the presence of a contralateral ovarian mass, and the patient's age. The cystic mass weighed 27 $\mathrm{kg}$. The masses were diagnosed as benign ovarian MCA.

\section{Discussion}

Giant ovarian cystadenomas are rarely observed today because of improved imaging techniques(5). Further, most ovarian cyst adenomas are epithelial cystadenomas, of which 25\% are mucinous(6). MCAs mainly occur during middle age, as in our case, and they are rare among adolescents. There was, however, a report of an ovarian MCA in a premenarchal girl(6). MCAs are usually unilateral, and are bilateral in 10\% of cases (as in our

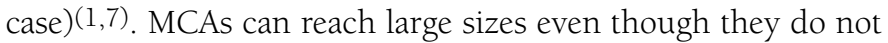
have the potential for malignancy $(1,3,8)$. The largest reported adnexal cyst was $148 \mathrm{~kg}(9)$. The mass in our patient weighed $27 \mathrm{~kg}$.

In general, MCAs can be found incidentally in routine USG screenings; abdominal enlargement and distension are major symptoms. The most frequent complications are torsion, pressure to the adjacent structures like the viscera, which accounts for urinary stasis and rupture, and spilling of tumor into the peritoneum, known as pseudomyxoma peritonei(7). In literature, there is no information about an ovarian mass presenting as DVT due to femoral vein pressure.

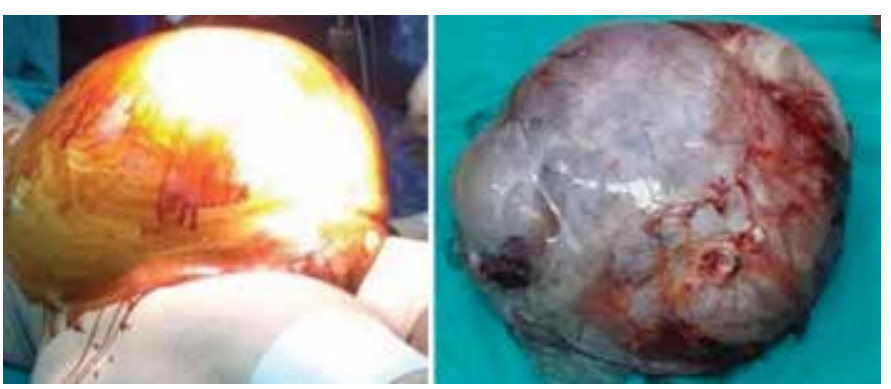

Figure 1. Massive distension of abdomen and giant mucinous ovarian cystadenoma
Ultrasonographic examination of ovarian cysts can exclude malignancy. In most cases, USG examination can reveal a complex adnexal mass, as in our case. When there is a diagnostic doubt, a CT or magnetic resonance imaging scan is performed. In our case, PET-CT scan was performed because of a suspicion of malignancy. Although tumor markers can identify cyst characterization in most instances, they are more important in monitoring postoperative relapse(6).

Large ovarian cysts traditionally require laparotomy because of their size(10). Cystectomy cannot be performed because of the absence of normal tissue; adnexectomy is the classic treatment. If there is a suspicion of malignancy, a laparotomy with oncologic procedures is recommended (7). Although some studies suggest laparoscopy, there are still debates because of tumor size limitations(10). We preferred laparotomy owing to the tumor dimension and suspicion of malignancy $(2,5)$.

Giant ovarian cysts have significant morbidity if not managed properly. A multidisciplinary approach must be taken preoperatively. Giant ovarian cysts can cause hemodynamic and pulmonary complications; therefore, central venous pressure monitorization is recommended during operations. The lateral decubitus position is preferred during the operation.

\section{Conclusion}

MCAs can present as different clinical conditions such as DVT. The appropriate treatment must include oncologic procedures, and a multidisciplinary approach must be undertaken to minimalize complications.

\section{Ethics}

Informed Consent: Consent form was filled out by all participants. Peer-review: Internal and Externally peer-reviewed.

\section{Authorship Contributions}

Surgical and Medical Practices: Esra Nur Tola, Evrim Erdemoğlu, Yakup Yalçın, Filiz Solmaz, Concept: Esra Nur Tola, Ebru Erdemoğlu, Design: Esra Nur Tola, Data Collection or Processing: Esra Nur Tola, Analysis or Interpretation: Esra Nur Tola, Literature Search: Esra Nur Tola, Writing: Esra Nur Tola, Evrim Erdemoğlu. Conflict of Interest: No conflict of interest was declared by the authors.

Financial Disclosure: The authors declared that this study has received no financial support.

\section{References}

1. Madhu YC, Harish K, Gotam P. Complete resection of a giant ovarian tumour. Gynecol Oncol Case Rep 2013;6:4-6.

2. Cirstoiu MM, Sajin M, Secara DC, Muntean O, Cirstoiu FC. Giant ovarian mucinous cystadenoma with borderline areas: a case report. Rom J Morphol Embryo 2014;55:1443-7.

3. Nwobodo EI.Giant mucinous cystadenoma: case report. Niger J Clin Pract 2013;13:228-9.

4. Rodriguez IM, Prat J. Mucinous tumors of the ovary: A clinicopathologic analysis of 75 borderline tumors (of intestinal type) and carcinomas. Am J Surg Pathol 2002;26:139-52. 
5. Kilincaslan H, Cipe G, Aydogdu I, Sarac F, Toprak H, Ari E. Pure laparoscopic management of a giant ovarian cyst in an adolescent. Am J Case Rep 2014;15:4-6.

6. Biçer S, Erkul Z, Demiryılmaz I, Peker N. A 9-kg ovarian mucinous cystadenoma in a 14-year-old premenarchal girl. Am J Case Rep 2014;15:326-9.

7. Posebella A, Galetti K, Engelberger S, Giovannacci L, Gyr T, Rosso R. A huge mucinous cystadenoma of ovarian: a rare case report and review of the literature. Rare Tumors 2014;6:5225.
8. Mikos T, Tabakoudis GP, Pados G, Eugenidis NP, Assimakopoulos E. Failure of ultrasound to diagnose a giant ovarian cyst: a case report. Cases J 2009;2:6909.

9. Spohn AE. Multicystic ovarian tumour weighing 328 pounds. Texas Med J 1905;1:1273-4.

10. Alobaid A, Memon A, Alobaid S, Aldakhil L. Laparoscopic management of huge ovarian cysts. Obstet Gynecol Int 2013;2013:380854. 